\title{
Article \\ Screening of Plant Pollen Sources, Polyphenolic Compounds, Fatty Acids and Antioxidant/Antimicrobial Activity from Bee Pollen
}

\author{
Yusuf Can Gercek 1,2,*(D), Saffet Celik ${ }^{3}(\mathbb{D})$ and Sinan Bayram ${ }^{4, *(\mathbb{D})}$ \\ 1 Department of Biology, Faculty of Science, Istanbul University, 34134 Istanbul, Turkey \\ 2 Centre for Plant and Herbal Products Research-Development, 34134 Istanbul, Turkey \\ 3 Technology Research and Development Application and Research Center, Trakya University, \\ 22030 Edirne, Turkey; saffetcelik@trakya.edu.tr \\ 4 Department of Medical Services and Techniques, Vocational School of Health Services, Bayburt University, \\ 69000 Bayburt, Turkey \\ * Correspondence: yusuf.gercek@istanbul.edu.tr (Y.C.G.); sbayram@bayburt.edu.tr (S.B.); \\ Tel.: +90-212-440-00-00 (Y.C.G.); +90-458-211-21-29 (S.B.)
}

Citation: Gercek, Y.C.; Celik, S.; Bayram, S. Screening of Plant Pollen Sources, Polyphenolic Compounds, Fatty Acids and Antioxidant/ Antimicrobial Activity from Bee Pollen. Molecules 2022, 27, 117. https://doi.org/10.3390/ molecules 27010117

Academic Editor: Lucia Panzella

Received: 17 November 2021 Accepted: 22 December 2021 Published: 26 December 2021

Publisher's Note: MDPI stays neutral with regard to jurisdictional claims in published maps and institutional affiliations.

Copyright: (C) 2021 by the authors. Licensee MDPI, Basel, Switzerland. This article is an open access article distributed under the terms and conditions of the Creative Commons Attribution (CC BY) license (https:// creativecommons.org/licenses/by/ $4.0 /)$.

\begin{abstract}
In this study, the botanical origin, total flavonoid and phenolic content, antioxidant activity, phenolic profile and fatty acid composition of mixed bee pollen loads collected in Bayburt, Turkey, were determined. In addition to these assays, antibacterial activity of bee-collected pollen extract (BCPE) against a variety of food-borne pathogenic bacteria was determined in vitro. Pollen loads were classified into five botanical families based on their color: Asteraceae, Fabaceae, Campanulaceae, Cistaceae and Rosaceae. Total flavonoid, total phenolic, CUPRAC and CERAC concentrations were $173.52 \mathrm{mg} \mathrm{GAE} / \mathrm{g}, 79.21 \mathrm{mg}$ QE/g, $85.59 \mathrm{mg}$ Trolox/g and $118.13 \mathrm{mg}$ Trolox/g, respectively. Twentythree phenolic compounds were scanned in bee pollen extract by LC-MS/MS, with rutin being the most abundant. Cis-4,7,10,13,16,19 docosahexaenoic acid was the predominant fatty acid, followed by cis-11-eicosenoic acid, palmitic acid, and alfa linolenic acid. In addition, the agar well diffusion (AWD) and micro-broth dilution methods were used to determine of the antibacterial activity of the BCPE sample. MIC values were observed to vary between $2.5-5 \mathrm{mg} / \mathrm{mL}$ for Gram-positive bacteria and $5-10 \mathrm{mg} / \mathrm{mL}$ for Gram-negative bacteria. These findings indicate that bee pollen could be a potential source of antioxidants and antimicrobials.
\end{abstract}

Keywords: bee pollen; fatty acid; polyphenolic profile; in vitro antibacterial activity

\section{Introduction}

In recent years, as the global population has increased, the global demand for nutrition has increased as well. People, particularly in developed and developing countries, prefer to eat healthily, and changes in consumer dietary habits occur [1]. With the understanding that natural/functional foods have a positive effect in the prevention and treatment of diseases, these foods have become more popular among the public [2]. Accordingly, numerous natural products, including bee products, have established a presence on market shelves and have begun to garner consumer interest. The bee products include honey, bee pollen, bee bread, royal jelly, beeswax, bee venom, apilarnil and beeswax [3]. One of these products, bee pollen, is collected from plant flowers by the honey bee. The collected flower pollen is accumulated as corbicular pellets in the pollen baskets located on the hind legs of the honey bee, and bee pollen is formed [4]. Bee pollen is classified in two groups according to its flower source: monofloral (the major taxon needs to be not less than $80 \%$ ) and polyfloral (which contains pollen from more than one plant taxon) [4].

Pollen is the primary source of protein for bees and thus can be considered a potential source of energy and protein for humans [1]. Pollen contains essential amino acids such as threonine, phenylalanine, histidine, lysine, leucine, methionine, valine, isoleucine, and tryptophan. Additionally, it contains digestible carbohydrates, reducing sugars, glucose and 
fructose, lipids, fatty acids, phenolic compounds, vitamins, macro-elements and microelements, but also bioactive substances such as flavonoids [5]. Bee pollen has been reported as possessing antimicrobial, antifungal, anti-inflammatory, antiviral, immunostimulant and local analgesic properties [5]. These beneficial effects of bee pollen on health are a result of the diverse array of secondary plant metabolites (niacin, tocopherol, thiamine, polyphenols, phytosterols) as well as coenzymes and enzymes contained in it [6]. Bee pollen is good source of polyphenol and flavonoid compounds, which have the ability to scavenge free radicals [6]. Bee pollen contains flavonoids such as rutin, quercitrin, isoquercitrin, naringenin, kaempferol, and luteolin [7]. Flavonoids that have antiviral, antibacterial, anti-oxidation, anti-aging, anti-inflammatory, anti-tumor and analgesic activities are among the main bioactive substances in bee pollen and important indicators of the quality of bee pollen [7]. The ratio of these substances in bee pollen largely depends on factors such as soil type, meteorological circumstances, and bee race, which vary according to plant origin and geographical origin [8-10].

Natural antioxidants can be isolated as pure individual compounds from different products and used for food preservation, as functional/supplements food, in cosmetics, and for therapeutic purposes [11]. Numerous studies on the antioxidant capacity of foods/food supplements including bee pollen have been conducted in recent years. Many studies have demonstrated that bee products, including pollen, contain significant amounts of natural antioxidants and exhibit a high level of antioxidant activity [10,12]. Bee pollen's antioxidant capacity varies according to the plant from which it is derived, as well as the geographical and climatic characteristics of the region in which it is provided [8-10]. Considering the differences that may arise from these changes, biological properties such as antioxidant activity, in particular, should be included in the standard studies to be conducted on pollen [12]. In addition, in order to determine the pollen's quality and conduct standardization studies, it is necessary to determine the pollen's plant origin via palynological analysis and then its chemical composition. This study was carried out by using bee pollen samples produced in Bayburt Region, which is located in the Eastern Black Sea Region of Turkey. Bayburt, an important province for beekeeping in Turkey, is located quite close to the production area of Turkey's most expensive honey, Anzer honey. Bee products produced in the Anzer Region are sold at higher prices than bee products produced in other regions of Turkey. Despite the close proximity of Bayburt to the Anzer Region, the fact that there is such a price difference causes the producers to suffer. For this reason, this study is very important in terms of presenting the quality of the pollen produced in the region as well as that of the plant resources that provide these samples with unique characteristics. It has been clearly demonstrated in many publications that the physical, physico-chemical, chemical and bioactive properties of plant-derived bee products such as honey and pollen vary depending on variables such as geographical location, climatic characteristics, collection time and most importantly plant sources. For this reason, determining the specific properties of products produced in different regions can contribute both to standardization studies in the future and to scientists' doing research in this field. In addition, determining the characteristics of local products can provide support to beekeepers who produce in that region to promote their products. As a matter of fact, in recent years, trust and demand for geographically indicated natural products has increased in Turkey, as in the whole world. Although numerous researchers have examined the palynological analysis of pollen samples produced in Turkey, to the best of our knowledge no research on the plant origin of pollen samples from Bayburt has been conducted. In this regard, this research has the characteristic of being a preliminary study. To contribute to standardization studies, the botanical origin, antioxidant capacity, total phenolic content, total flavonoid content, phenolic profile and fatty acid content of bee pollen extract were evaluated in this study. 


\section{Results and Discussions}

\subsection{Botanical Origin of Bee Pollen Loads}

The pollen loads examined here were collected directly from hives and consisted of a mixture of pollen types from a variety of plant species, namely Asteraceae, Fabacea, Campanulaceae, Cistaceae and Rosacaeae. Numerous studies similar to ours have determined the botanical origins of bee pollen samples. Mayda et al. [10] identified different plant taxa in pollen samples collected from beehive samples in various regions of Turkey. These researchers identified Asteraceae (Centaurea sp., Cichorium sp., Helianthus sp., Taraxacum sp., Xanthium sp., Senecio sp., Conyza sp., Solidago sp., Crepis sp., Bellis sp., Carduus sp.), Apiaceae (Daucus sp.,), Berberidaceae (Berberis sp.), Betulacae, Boraginacea (Echium sp., Myosotis sp.), Brassicaceae, Caryophyllaceae (Dianthus sp.), Chenopodiaceae, Cistaceae (Cistus sp.), Dipsacaceae, Fabaceae (Astragalus sp., Coronilla sp., Onobrychis sp., Trifolium sp., Lotus sp., Trifolium pratense, Melilotus sp., Hedysarum sp.), Fagaceae (Castanea sativa), Geraniaceae, Hypericaceae (Hypericum sp.), Lamiaceae (Salvia sp., Teucrium sp., Thymus sp.), Lauracaeae (Laurus sp.), Myrtaceae (Eucalyptus sp.), Papveraceae, Plantaginaceae, Poaceae (Zea mays), Polyganaceae (Rumex sp.), Ranunculaceae, Rosaceae (Fragaria sp., Linaria sp., Pyrus sp., Sarcopoterium sp., Sanguisorba sp.), Tiliaceae (Tilia sp.), Loranthaceae (Loranthus sp.), Scrophulariaceae (Linaria sp.), Salicaceae (Salix sp.), Ericaceae (Rhododendron sp.) and Solanaceae taxa as the botanical origin of pollen samples from different regions of Turkey. Almeida-Muradian et al. [13] revealed that pollens from the Arecaceae, Asteraceae and Myrtaceae families are abundant in bee pollen. Feás et al. [14] discovered the presence of pollens belonging to nine taxa in samples of bee pollen from Portugal. In their studies, it was determined that bees' most visited plants for collecting pollen were Cistaceae and Boraginaceae family members, and the least visited plants were Myrtaceae family members. In Turkey, agriculture and vegetation are different, which results in the formation of important resources for beekeeping. Therefore, the nutritional value and chemical content of bee pollen varies depending on the plant species from which it is collected [10]. The morphological structure of pollen varies significantly between plant species [15]. Therefore, it is possible to encounter a variety of pollens of all kinds of colors, shapes and surface structures [15]. Although pollen is generally yellow, it is possible to encounter pollens of various colors such as red, purple, pink, lilac, green and black [16]. Due to the bee's approximately $5 \mathrm{~km}$ flight range, it is impossible to determine with a naked eye where and from which plant the bee collects pollen [16-18]. Therefore, pollen analysis is critical to determine the botanical sources of bee pollen obtained from different plant sources, such as those in this study.

\subsection{Total Phenolic/Flavonoid Content and Antioxidant Capacity}

All plants produce a large number of phenolic substances as secondary metabolites in their metabolism $[19,20]$. For this reason, there are always different amounts of various phenolic compounds in all plant-based foods. Phenolic compounds are divided into phenolic acids and flavonoids. It is known that phenolic compounds found in natural plants are effective at protecting the human body against free radicals [21]. These compounds exhibit a variety of beneficial properties such as anticarcinogenic, antioxidant, antiapoptotic, anti-atherosclerosis, anti-inflammation, cardiovascular protection, anti-aging, and enhancement of endothelial function, as well as inhibition of angiogenesis and cell proliferation activity [22]. Bee pollen also contains relatively high amounts of phenolics, and the flavonoids $(0.2-2.5 \%)$ are the main compounds [23]. In this study, the total phenolic content of pollen extract from mixed pollen types was calculated spectrophotometrically using the Folin-Ciocalteu method as an equivalent to gallic acid. In addition, the total flavonoid content was calculated using the aluminum chloride method to be equivalent to quercetin. As shown in Table 1, significant quantities of total phenolic and total flavonoid content were recorded in bee pollen extract $173.52 \pm 1.87 \mathrm{mg}$ GAE/g and $79.21 \pm 5.89 \mathrm{mg} \mathrm{QE} / \mathrm{g}$, respectively. The total phenolic content obtained in this study was within the range reported for Anzer pollens from Turkey (44.07-124.20 mg GAE/g) [24] and pollens from Brazil (41.5-213.2 mg GAE/g) [25], but was 
higher than that reported for Turkish pollen samples (7.88 mg GAE/g and $17.46 \mathrm{mg}$ ) [26], Italian pollens (13.53-24.75 mg GAE/g) [27], Romanian pollens (4.4-16.4 mg GAE/g) [28], and Portuguese pollens (10.5-16.8 mg GAE/g) [29]. Similarly, the flavonoid content of pollen extract has been determined in various studies in different ratios, such as $4.5-7.1 \mathrm{mg}$ CAE/g, $1.81-4.44 \mathrm{mg} / \mathrm{g}$ QE/g [10] and 1.42-9.05 mg QE/g [8], but Bayburt pollen has a higher flavonoid content than these. In addition, a different study discovered that Bayburt honey contained fewer total phenolics (219.43 mg GAE/ kg-768.82 mg GAE/ kg) than the pollen sample [30]. The amounts of $1358 \pm 90 \mathrm{mg}$ GA/100 g total phenolics were reported for heterofloral Bayburt bee pollen [26], which was lower than the total phenolics of our pollens. The total phenolic and total flavonoid content of twenty-two different pollen samples from Portugal were determined as 12.9-19.8 mg GAE/g and 4.5-7.1 mg CAE/g, respectively [14]. In comparison with the literature, the pollen extract's total phenolic and total flavonoid content is quite high, indicating that the pollen extract from Bayburt has a high antioxidant activity.

Table 1. Antioxidant properties of pollen extract.

\begin{tabular}{cccc}
\hline TPC $(\mathbf{m g ~ G A} / \mathrm{g})$ & TFC $(\mathbf{m g}$ QE/g) & CUPRAC $(\mathbf{m g}$ Trolox/g) & CERAC $(\mathbf{m g}$ Trolox/g) \\
\hline $173.52 \pm 1.87$ & $79.21 \pm 5.89$ & $85.59 \pm 5.95$ & $118.13 \pm 19.90$ \\
\hline
\end{tabular}

Especially in recent years, as the incidence of numerous diseases such as cancer has increased, it has become critical to determine the activities of foods or food supplements used as antioxidants. When evaluated in this respect, many techniques (CUPRAC, CERAC, DPPH, FRAP, ORAC, ABTS, etc.) are used to determine the antioxidant capacity of foods [31]. In this study, CUPRAC and CERAC methods were used to test the antioxidant capacity of bee pollen, which is one of the products proven in the literature to have antioxidant properties [32] (Table 1). The bee pollen extract analyzed in this study was found to possess significant antioxidant activity as well as a variety of phenolic and flavonoid compounds. Some authors reported similar correlations between phenolic content and antioxidant activity using various methods [33-35]. Anzer pollen was found to have remarkable antioxidant activity (11.77 to $105.06 \mu \mathrm{mol}$ Trolox/g pollen) in a similar study [24]. Altıner et al. [36] investigated the antioxidant capacity of extracts of bee pollen from specific floral regions in Turkey. Altıner et al. [36] reported that antioxidant capacities of pollen samples were 83.24-257.27 $\mu \mathrm{mol} \mathrm{TE} / \mathrm{g}$ by the CUPRAC method.

\subsection{Polyphenolic Profile}

The number of studies on the characterization of phenolic compounds in bee pollen has increased in recent years, as phenolic compounds have been recognized as potentially useful taxonomic markers [37]. The content of bee pollen varies significantly depending on the geographical origin, harvested time and plant source [38]. While the chemical, physicochemical and sensory properties of monofloral pollen are similar, these properties are quite different for heterofloral pollen samples. In this study, the heterofloral pollen extract's polyphenolic profile was evaluated qualitatively and quantitatively using LC-MS/MS for 23 phenolic compounds. The concentrations of individual compounds in the pollen extract are summarized in Table 2. Sixteen of them were identified in the extract based on standard retention times and mass spectra. Gallic acid, protocatechuic acid, syringic acid, 2,5-dihydroxybenzoic acid, caffeic acid, salicylic acid, catechin, rutin, $p$-coumaric acid, trans ferulic acid, phlorizin, myricetin, luteolin, quercetin, kaempferol and isorhamnetin were all present in different amounts in the pollen sample, whereas chlorogenic acid, sinapinic acid, naringin, ethyl gallate, propyl gallate, 2-hydroxytranscinnamic acid and resveratrol were present below their limits of detection. The results indicated that the extract contained a high concentration of phenolics. The major phenolic compound in bee pollen extract was rutin $(115,442.25 \pm 7774.28 \mu \mathrm{g} / \mathrm{kg})$, followed by kaempferol, quercetin, myricetin and $p$-coumaric acid at contents of $9870.72 \pm 790.14,7849.8 \pm 528.63,2220.70 \pm 177.76$, $1508.98 \pm 91.89 \mu \mathrm{g} / \mathrm{kg}$, respectively. However, rutin, quercetin and kaempferol have been 
reported at high rates in many previous studies $[39,40]$. Rutin, which is believed to contribute to antioxidant activity [41], can be used as a chemical marker for bee pollen. However, caffeic acid, isoquercitrin, galangin and chrysin were determined as "key markers" in monofloral and heterofloral bee pollen samples from different botanical and geographical origins [42]. On the other hand, the presence of $p$-coumaric acid, ferulic acid, rutin, myricetin, quercetin and kaempferol phenolics in bee pollen samples has also been shown in previous studies [43]. However, kaempferol and myricetin phenolics were found only in low quantities in chestnut pollen samples from the Black Sea Region, Turkey [44]. This may be due to the monofloral nature of the pollen sample. As a matter of fact, in some studies, it has been determined that heterofloral bee pollen samples have richer bioactive content compared to monofloral pollen samples [42]. As in our study, the following flavonoids and their derivatives were identified as components of Morocco bee pollen: ferulic acid $(17.17 \mathrm{mg} / \mathrm{kg}), \mathrm{o}-$ coumaric acid $(27.10 \mathrm{mg} / \mathrm{kg})$, chlorogenic acid (not detected), catechin (not detected), naringin $(113.71 \mathrm{mg} / \mathrm{kg})$, quercetin $(48.12 \mathrm{mg} / \mathrm{kg})$, rutin $(95.36 \mathrm{mg} / \mathrm{kg})$, resveratrol (44.00 mg/ $\mathrm{kg}$ ), and kaempferol (not detected) [45]. In addition, Thakur and Nanda [40] reported that the concentration of flavonoids (catechin: 0.94-19.10 mg/100 g; rutin: $4.81-24.83 \mathrm{mg} / 100 \mathrm{~g}$; quercetin: $3.14-15.94 \mathrm{mg} / 100 \mathrm{~g}$; luteolin: $1.06-5.86 \mathrm{mg} / 100 \mathrm{~g}$; kaempferol: $0.12-9.35 \mathrm{mg} / 100 \mathrm{~g}$; and apigenin: $0.46-3.02 \mathrm{mg} / 100 \mathrm{~g}$ ) varied depending on the botanical origin. In a study related to bee pollen phenolics, Ulusoy and Kolayli (2014) [24] investigated the flavonoid content in Turkey bee pollen and determined gallic acid, protocatechuic acid, caffeic acid, rutin and quercetin phenolics. The types and concentrations of phenolic compounds in pollen samples from various geographical sources may have differed depending on the botanical origin and climatic conditions, as well as the processing and storage conditions.

Table 2. Concentrations of polyphenolic compounds in pollen extract ( $\mu \mathrm{g} / \mathrm{kg})$.

\begin{tabular}{|c|c|c|c|c|c|c|}
\hline Compounds & $\begin{array}{l}\text { Retention Time } \\
\text { (min) }\end{array}$ & RSD (\%) & $\begin{array}{c}{[\mathbf{M}-\mathbf{H}]^{-}} \\
m / z\end{array}$ & Ion Pair & $\mathbf{R}^{2}$ (Linearity) & $\begin{array}{l}\text { Concentrations } \\
(\mu \mathrm{g} / \mathrm{kg})\end{array}$ \\
\hline Gallic acid & 1.552 & 0.482 & 168.9 & $\begin{array}{l}168.9 / 125 \\
168.9 / 78.8\end{array}$ & 0.9983 & $585.52 \pm 31.84$ \\
\hline Protocatechuic acid & 1.830 & 0.482 & 153.1 & $\begin{array}{l}153.1 / 109.1 \\
153.1 / 90.8\end{array}$ & 0.9980 & $441.94 \pm 21.13$ \\
\hline $\begin{array}{l}\text { 2,5-Dihydroxybenzoic } \\
\text { acid }\end{array}$ & 2.084 & 0.482 & 152.9 & $\begin{array}{l}152.9 / 107.9 \\
152.9 / 53.1\end{array}$ & 0.9966 & $58.80 \pm 3.95$ \\
\hline Caffeic acid & 3.579 & 0.488 & 179 & $\begin{array}{l}179 / 135.1 \\
179 / 117.3\end{array}$ & 0.9983 & $928.56 \pm 74.33$ \\
\hline Syringic acid & 3.603 & 0.489 & 196.9 & $\begin{array}{l}\text { 196.9/182.1; } \\
\text { 196.9/121.1 }\end{array}$ & 0.9967 & $284.24 \pm 17.30$ \\
\hline Salicyclic acid & 3.691 & 0.577 & 136.8 & $\begin{array}{c}136.8 / 93.1 \\
136.8 / 65\end{array}$ & 0.9947 & $314.11 \pm 4.39$ \\
\hline Chlorogenic acid & 3.701 & 0.488 & 352.9 & $\begin{array}{c}352.9 / 191 \\
352.9 / 82\end{array}$ & 0.9982 & $\mathrm{Nd}$ \\
\hline Catechin & 3.888 & 1.155 & 288.9 & $\begin{array}{l}288.9 / 245 \\
288.9 / 205\end{array}$ & 0.9971 & $37.26 \pm 1.78$ \\
\hline Rutin & 3.911 & 0.494 & 609 & $\begin{array}{l}609 / 299.9 \\
609 / 270.9\end{array}$ & 0.9975 & $115442.25 \pm 7774.28$ \\
\hline Sinapic acid & 3.924 & 0.417 & 222.9 & $\begin{array}{c}222.9 / 208 \\
222.9 / 120.9\end{array}$ & 0.9946 & $\mathrm{Nd}$ \\
\hline$p$-Coumaric acid & 3.986 & 0.551 & 163.1 & $\begin{array}{c}163.1 / 118.9 \\
163.1 / 93\end{array}$ & 0.9972 & $1508.98 \pm 91.89$ \\
\hline Naringin & 4.030 & 0.491 & 579.1 & $\begin{array}{c}579.1 / 458.9 \\
579.1 / 271\end{array}$ & 0.9990 & $\mathrm{Nd}$ \\
\hline Trans ferulic acid & 4.045 & 0.442 & 193 & $\begin{array}{l}193 / 177.9 \\
193 / 134.1\end{array}$ & 0.9982 & $151.84 \pm 8.25$ \\
\hline Ethyl gallate & 4.078 & 0.492 & 197 & $197 / 169 ; 197 / 124$ & 0.9971 & $13.45 \pm 0.64$ \\
\hline Phlorizin & 4.081 & 0.540 & 434.1 & $\begin{array}{c}434.8 / 272.9 \\
434.8 / 167\end{array}$ & 0.9977 & $\mathrm{Nd}$ \\
\hline
\end{tabular}


Table 2. Cont.

\begin{tabular}{|c|c|c|c|c|c|c|}
\hline Compounds & $\begin{array}{l}\text { Retention Time } \\
\text { (min) }\end{array}$ & RSD (\%) & $\begin{array}{c}{[\mathbf{M}-\mathbf{H}]^{-}} \\
\quad m / z\end{array}$ & Ion Pair & $\mathbf{R}^{2}$ (Linearity) & $\begin{array}{c}\text { Concentrations } \\
(\mu \mathrm{g} / \mathrm{kg})\end{array}$ \\
\hline Myricetin & 4.167 & 0.058 & 317 & $\begin{array}{l}317 / 178.8 \\
317 / 150.9\end{array}$ & 0.9961 & $2220.70 \pm 177.76$ \\
\hline Propyl gallate & 4.171 & 0,539 & 211 & $211 / 124.1 ; 211 / 78$ & 0.9963 & $\mathrm{Nd}$ \\
\hline $\begin{array}{l}\text { 2-Hydroxytranscinnamic } \\
\text { acid }\end{array}$ & 4.173 & 0,477 & 162.9 & $\begin{array}{l}162.9 / 119 ; \\
162.9 / 92.8\end{array}$ & 0.9972 & $\mathrm{Nd}$ \\
\hline Resveratrol & 4.314 & 0.491 & 226.9 & $\begin{array}{l}226.9 / 184.9 \\
226.9 / 142.8\end{array}$ & 0.9983 & $\mathrm{Nd}$ \\
\hline Luteolin & 4.321 & 0.981 & 284.9 & $\begin{array}{c}284.9 / 150.9 \\
284.9 / 133\end{array}$ & 0.9966 & $250.47 \pm 11.97$ \\
\hline Quercetin & 4.346 & 0.473 & 301 & $\begin{array}{l}301 / 178.9 \\
301 / 150.9\end{array}$ & 0.9964 & $7849.8 \pm 528.63$ \\
\hline Kaempferol & 4.406 & 0.956 & 284.9 & $\begin{array}{l}284.9 / 226.9 \\
284.9 / 93\end{array}$ & 0.9985 & $9870.72 \pm 790.14$ \\
\hline Isorhamnetin & 4.421 & 0.489 & 314.9 & $\begin{array}{c}314.9 / 299.9 \\
314.9 / 151\end{array}$ & 0.9980 & $523.545 \pm 31.88$ \\
\hline
\end{tabular}

Nd: not detected.

\subsection{Fatty Acid Composition}

Bee pollen's diversity of compounds makes it the most important nutrient for bees while also serving as a good food supplement for humans [9,46]. Pollen grains contain between $1 \%$ and $20 \%$ of lipid substances [9]. Around 3\% of total lipids are free fatty acids, about half of which are unsaturated acids like oleic, linolenic (omega-3) and linoleic (omega-6) [12,47]. The fatty acid content varied between 0.52 and $8.21 \%$. In this study, 13 fatty acids were identified in the pollen extract. Individual percentages of each fatty acid are given in Table 3. Cis-4,7,10,13,16,19 docosahexaenoic acid (C22:6n3) was determined as the predominant fatty acid $(8.21 \%)$ in the pollen sample, and cis-11-eicosenoic acid (C20:1n9) was detected as the second most abundant fatty acid in the extract, accounting for $7.27 \%$. In addition, alpha-linolenic acid, a source of omega-3 fatty acids, was the fourth type of fatty acid detected in the pollen extract, with a share of $5.25 \%$. Since omega- 3 and omega- 6 fatty acids cannot be synthesized in the human body, they must be obtained from food [48]. In addition, alpha-linolenic acid is a precursor for the synthesis of EPA and DHA, which are not synthesized in the human body and which have many important functions in the body [48]. These findings suggest that pollen extracts can be potentially used as a source of omega-3.

Table 3. Fatty acid composition of pollen sample.

\begin{tabular}{cccc}
\hline Fatty Acids & Formula & Retention Time & \% of Total \\
\hline Caprylic acid & C8:0 & 5.022 & $0.52 \pm 0.03$ \\
Capric acid & C10:0 & 6.118 & $2.89 \pm 0.08$ \\
Lauric acid & C12:0 & 7.191 & $1.53 \pm 0.01$ \\
Myristic acid & C14:0 & 8.531 & $0.74 \pm 0.03$ \\
Palmitic acid & C16:0 & 10.382 & $5.5 \pm 0.31$ \\
Stearic acid & C18:0 & 12.789 & $1.72 \pm 0.05$ \\
Oleic acid & C18:1n9t & 13.121 & $3.95 \pm 0.03$ \\
Linoleic acid & C18:2n6c & 13.793 & $3.1 \pm 0.13$ \\
Alfa linolenic acid & C18:3n3 & 14.662 & $5.25 \pm 0.30$ \\
Cis-11-Eicosenoic acid & C20:1n9 & 15.959 & $7.27 \pm 0.21$ \\
Erucic acid & C22:1n9 & 18.936 & $5.54 \pm 0.04$ \\
Nervonic acid & C24:1n9 & 21.728 & $2.21 \pm 0.09$ \\
Cis-4,7,10,13,16,19 & C22:6n3 & 21.892 & $8.21 \pm 0.46$ \\
Docosahexanoic acid & & & \\
\hline
\end{tabular}

The results obtained for the fatty acid profile of the pollen extract examined in this study are consistent with those obtained in previous studies in the literature, including in the works of Kostic et al. [9] and Araújo et al. [8]. In fact, Kostic et al. [9] investigated the 
fatty acid profile of Serbian bee-collected pollen and discovered twenty different fatty acids, with palmitic, oleic and linolenic acids being the most abundant, respectively. Likewise, Sagona et al. [49] reported on a similar fatty acid profile for monofloral organic Tuscanian bee pollen samples of different botanical origins, which contained $\alpha$-linolenic acid and linoleic acid as dominant fatty acids. Mărgăoan et al. [50] detected 14 different polyunsaturated fatty acids in multifloral bee pollen samples from Romania. They detected a high concentration of $\alpha$-linoleic acid (20.28-49.37\%), followed by linoleic acid (7.62-33.93\%), oleic acid (3.68-15.34\%). In pollen samples from the Bingöl Region, Karagözoğlu et al. [51] reported that palmitic acid ranged between $24.25 \%$ and $32.49 \%$, stearic acid ranged between $1.07 \%$ and $1.95 \%$, oleic acid between $5.3 \%$ and $9.03 \%$, linoleic acid between $8.56 \%$ and $10.76 \%$ and $\alpha$-linolenic acid between $27.26 \%$ and $36.53 \%$. In addition, these researchers stated that by analyzing the fat content of pollen, they could determine its biological value and nutritional quality. Compared to our study, Mărgăoan et al. [50] and Karagözoğlu et al. [51] reported higher concentrations of fatty acid content in pollen samples. These differences may be due to the fact that the pollen samples were obtained from different botanical and geographical sources, as well as the methodological differences (fatty acid extraction method/extraction solvent, etc.) used in the studies.

\subsection{In Vitro Antibacterial Activity}

The agar well diffusion (AWD) method was used in this study to determine the in vitro antibacterial activity of bee-collected pollen extracts (BCPE) against different food-borne pathogens. For this purpose, the dry residue from the prepared BCPE was weighed and dissolved in $80 \%$ DMSO. Thus, a solution containing $20 \mathrm{mg} / \mathrm{mL}$ of the extract was prepared and used to determine its in vitro antibacterial activity (Table 4). As a result, we observed that the inhibition zone diameters for Gram-positive bacteria ranged between 15-18 $\mathrm{mm}$ at the end of the $24 \mathrm{~h}$ incubation period (Bacillus cereus ATCC 14579: $15 \mathrm{~mm}$; Staphylococcus aureus NCTC 10788: $18 \mathrm{~mm}$ ). In addition, for Gram-negative bacteria, it was observed that the inhibition zone diameters varied between 9 and $12 \mathrm{~mm}$ (Escherichia coli ATCC BAA 25-23: 9 mm; Salmonella Typhimurium RSSK 95091: 12 mm).

Table 4. In vitro antibacterial activity of BCPE (at a concentration of $20 \mathrm{mg} / \mathrm{mL}$ ) via agar well diffusion (AWD) method. (Inhibition zone diameter (IZD: $\mathrm{mm}$ ) and minimum inhibition concentration (MIC$\mathrm{mg} / \mathrm{mL}$ ). For negative control (NC), 80\% DMSO was used.)

\begin{tabular}{|c|c|c|c|c|}
\hline & \multirow{2}{*}{ Microorganisims } & \multicolumn{2}{|c|}{ BCPE } & \multirow{2}{*}{$\frac{\mathrm{NC}}{\mathrm{IZD}}$} \\
\hline & & IZD & MIC & \\
\hline \multirow{5}{*}{ Gram positive } & Bacillus cereus ATCC 14579 & 15 & 2.5 & - \\
\hline & Bacillus cereus BC 6830 & 16 & 2.5 & - \\
\hline & Staphylococus aureus ATCC 25923 & 18 & 2.5 & - \\
\hline & Staphylococus aureus BC 7231 & 17 & 2.5 & - \\
\hline & Staphylococus aureus NCTC 10788 & 18 & 5 & - \\
\hline \multirow{7}{*}{ Gram negative } & Escherichia coli ATCC BAA 25-23 & 9 & 10 & - \\
\hline & Escherichia coli BC 1402 & 10 & 10 & - \\
\hline & Escherichia coli NCTC 9001 & 10 & 10 & - \\
\hline & Pseudomonas aeruginosa ATCC 9070 & 10 & 10 & - \\
\hline & Pseudomonas aeruginosa NCTC 12924 & 10 & 10 & - \\
\hline & Salmonella typhimurium RSSK 95091 & 12 & 5 & - \\
\hline & Yersinia enterocolitica ATCC 27729 & 11 & 10 & - \\
\hline
\end{tabular}

Following these procedures, the broth micro-dilution technique was used to determine the BCPE sample's minimum inhibition concentration (MIC) values against a panel of food-borne pathogens. At the end of this procedure, it was observed that the MIC values against Gram-positive microorganisms ranged from 2.5 to $5 \mathrm{mg} / \mathrm{mL}$ (for Staphylococcus aureus NCTC 10788, MIC value $5 \mathrm{mg} / \mathrm{mL} ; 2.5 \mathrm{mg} / \mathrm{mL}$ for other Gram-positive bacteria). MIC values for Gram-negative bacteria were found to be between 5 and $10 \mathrm{mg} / \mathrm{mL}$ (MIC 
value of Salmonella Typhimurium RSSK $950915 \mathrm{mg} / \mathrm{mL}$; for other Gram-negative bacteria, $10 \mathrm{mg} / \mathrm{mL}$ ).

Graikou et al. [52] reported that Greek pollen samples have antioxidant, antimicrobial and proteasome activation properties. In addition, they stated that Gram-positive bacteria were more sensitive than Gram-negative bacteria to pollen extract. However, it should be noted that our study obtained higher MIC values than this study. Mohdaly et al. [53] investigated the antioxidant properties and antibacterial activity of pollen and propolis methanol extracts. Similarly, pollen extracts were found to be effective against both Gram-positive and Gram-negative bacteria in this study. In addition, MIC values were found to be lower in Gram-positive bacteria than in Gram-negative bacteria. When all of these findings are considered together, it becomes clear that the findings of this study are also consistent with the results obtained in our study. Additionally, Cabrera and Montenegro [54] determined the antimicrobial activity of pollen aqueous extract against $S$. aureus, Streptococcus pyogenes, E. coli and P. aeruginosa bacteria. These researchers found higher MIC values for pollen extracts compared to our study. One possible explanation for this observed difference is that the pollen samples were extracted with water. In conclusion, when antibacterial activity is considered, the results of this study indicate that BCPE has an inhibitory effect against food-borne pathogens at various concentrations. As can be seen, these findings are quite consistent with and corroborate those previously published in the literature.

\section{Materials and Methods}

\subsection{Bee Pollen Loads and Determination of Their Botanical Origin}

Bee pollen sample loads were collected in 2018 from Bayburt, Turkey, with bottomfitted pollen traps. The pollen samples were stored at $-18^{\circ} \mathrm{C}$ until analysed. The botanical origin of the bee pollen loads was prepared according to Wodehouse [55]. A few drops of $96 \%$ ethyl alcohol were dropped on the pollen on the slide. The preparation was allowed to stand on the heater until the alcohol evaporated. A portion of basic fuchsine added glyceringelatin was placed on the pollen and mixed. Pollen grains were examined by a Leica DM500 light microscope and diagnosed using an immersion objective lens $(\times 100)[17,56]$.

\subsection{Preparation of Bee Pollen Extract}

Bee pollen samples collected from the hive were pulverized using a grinder. After that, a $1.5 \mathrm{~g}$ sample was dissolved in $10 \mathrm{~mL}$ ethanol (95\%) followed by ultrasonic-assisted extraction in an ultrasonic cleaning bath for $60 \mathrm{~min}$ at $40{ }^{\circ} \mathrm{C}$. The mixture was centrifuged for $30 \mathrm{~min}$ at $3500 \mathrm{rpm}$ and then the supernatant was collected. Extraction was repeated two more times and supernatants were combined in a flask. The extract was filtered through a $0.45 \mu \mathrm{m}$ membrane and diluted to the appropriate concentration as per calibration curves [57].

\subsection{Yield of Extraction}

Extraction efficiency is a measure of the efficiency of the solvent and method for the extraction of phytochemical components. In the scope of our study, the extraction efficiency of bee pollen samples was calculated by making some modifications to the study conducted by Zhang et al. [58]. The solvent of the extract was removed from the Miulab NKD-200/2 model under nitrogen $\left(40^{\circ} \mathrm{C}\right.$, flow $1 \mathrm{~mL} / \mathrm{min}$, duration $\left.8 \mathrm{~min}\right)$. The extract was incubated at $-80{ }^{\circ} \mathrm{C}$ for $1 \mathrm{~h}$ and freeze dried for $24 \mathrm{~h}$ at $-52{ }^{\circ} \mathrm{C}$ and 0.05 mbar pressure with a Christ Alpha 1-2LD model lyophilizator and the sample was weighed.

Extraction yield $(\%)=($ weight of freeze - dried extract $\times 100) /($ the weight before the process $)$

\subsection{Total Phenolic Content (TPC)}

TPC was determined using a modified Folin-Ciocalteu method by a microplate reader (Epoch Microplate Spectrophotometer, BioTek Instruments, Inc.) using spectrophotometric detection and microtiter 96 -well plates. To start, $50 \mu \mathrm{L}$ of the extract and $50 \mu \mathrm{L}$ of 
Folin-Ciocalteu reagent $(1: 5, v / v)$ were placed in each well. After that, $100 \mu \mathrm{L}$ of sodium hydroxide solution $(0.35 \mathrm{M})$ was added. The absorbance at $760 \mathrm{~nm}$ of the blue complex formed was monitored after $3 \mathrm{~min}$. The results were expressed as gallic acid equivalent (mg GAE/g) [59].

\subsection{Total Flavonoid Content (TFC)}

Total flavonoid analysis of the extract was performed by a modified version of the method used by Jia et al. [60]. Accordingly, an aliquot (1 mL) extract was mixed with $0.3 \mathrm{~mL} 10 \% \mathrm{AlCl}_{3} \cdot 6 \mathrm{H}_{2} \mathrm{O}$ solution after the addition of $0.3 \mathrm{~mL} 5 \% \mathrm{NaNO}_{2}$ solution. Then, $2 \mathrm{~mL}$ of $1 \mathrm{M} \mathrm{NaOH}$ solution was added, $2.4 \mathrm{~mL}$ of water was added, and the mixture was stirred. At $510 \mathrm{~nm}$ the absorbance was measured against the prepared reagent blank a microplate spectrophotometer (Epoch Microplate Spectrophotometer, BioTek Instruments, Inc., Winooski, VT, USA). TFC was expressed as mg quercetin equivalent (mg QE/g).

\subsection{Antioxidant Activity}

\subsubsection{Cupric ion Reducing Antioxidant Capacity (CUPRAC) Assay}

In a test tube, $1 \mathrm{~mL}$ of $1.0 \times 10^{-2} \mathrm{M}$ copper (II) chloride solution, $1 \mathrm{~mL}$ of $7.5 \times 10^{-3} \mathrm{M}$ neocuproine solution and $1 \mathrm{~mL}$ of $1 \mathrm{M}$ ammonium acetate buffer $(\mathrm{pH}=7.0)$ were added and mixed. Then, $0.1 \mathrm{~mL}$ of antioxidant sample solutions and $1 \mathrm{~mL}$ of distilled water were added to these solutions. The final volume of the mixture was $4.1 \mathrm{~mL}$. Tubes were kept at room temperature with cover closed for $30 \mathrm{~min}$. At the end of the period, the absorbances of the solutions at $450 \mathrm{~nm}$ were measured against the reagent blank and compared to a Trolox standard curve 1-20 mM [61].

\subsubsection{Ce(IV)-Based Reducing Capacity (CERAC) Assay}

The total antioxidant capacity of the samples was also detected using of the Cerium (IV) assay of Ozyurt et al. [62]. This involved adding $1 \mathrm{~mL}$ of $2.0 \times 10^{-3} \mathrm{M} \mathrm{Ce}(\mathrm{IV})$ solution to $1 \mathrm{~mL}$ of extract. Then, the mixture was diluted to $10 \mathrm{~mL}$ with distilled water and the solution was allowed to stand for $30 \mathrm{~min}$ at room temperature. The absorbance of the mixture was measured at $320 \mathrm{~nm}$ against a reagent blank composed of distilled water and compared to a Trolox standard curve 1-20 mM.

\subsection{Liquid Chromatography-Triple Quadrupole Mass Spectroscopy (LC-MS/MS) Analysis}

Extraction was carried out via modified methods of isolation of phenolic compounds developed by Fischer et al. [63]. First, $100 \mu \mathrm{L}$ of extract was mixed with $900 \mu \mathrm{L}$ extraction solution and, afterward, the samples were vortexed for $30 \mathrm{~s}$. After that, the mixture was homogenized using a sonicator (WiseClean, DAIHAN) for $10 \mathrm{~min}$, centrifuged for $5 \mathrm{~min}$ at $3500 \mathrm{rpm}$, and the clear supernatant was injected into the LC-MS/MS system for analysis.

\subsection{Fatty Acid Methyl Ester Analysis}

\subsubsection{Lipid Extraction}

The bee pollen sample was freeze-dried for approximately $24 \mathrm{~h}$ to a constant mass and ground to a homogenous powder using a coffee blender. Soxhlet extraction was performed in a BUCHI Extraction System B-811 (Buchi, Switzerland). Soxhlet extraction of the bee pollen $(2 \mathrm{~g})$ was performed with $100 \mathrm{~mL}$ hexane for approximately $8 \mathrm{~h}$.

\subsubsection{Methylation Procedure}

Fatty acid methyl esters were prepared with some modifications following the IUPAC methodology. A $100 \mathrm{mg}$ sample of pollen oil was dissolved in $10 \mathrm{~mL}$-hexane (GC grade). A methanolic potassium hydroxide $(\mathrm{KOH})$ solution $(2 \mathrm{~N})$ was added $(0.1 \mathrm{~mL})$. The tube was sealed and mixed vigorously for $120 \mathrm{~s}$ in a vortex shaker. Saturated sodium chloride $(\mathrm{NaCI})$ solution $(2 \mathrm{~mL})$ was added, and the organic phase was separated. An aliquot $(1 \mu \mathrm{L})$ of the hexane solution was injected to GC analysis [64]. 


\subsubsection{Gas Chromatography-Mass Spectroscopy (GC-MS) Conditions}

Methylated fatty acid samples were analyzed by Agilent 6890A GC gas chromatography and 5973C MSD mass spectrometry. The components were separated in a fused silica capillary column DB-23 (60 $\mathrm{m} \times 0.25 \mathrm{~mm}$ ID, $0.15 \mu \mathrm{m}$; J \& W 122-2361). The oven temperature was maintained at $50{ }^{\circ} \mathrm{C}$ for $1 \mathrm{~min}, 25^{\circ} \mathrm{C}$ increments at $175{ }^{\circ} \mathrm{C}$, and $4{ }^{\circ} \mathrm{C}$ increments at $230{ }^{\circ} \mathrm{C}$ for $5 \mathrm{~min}$. The injection temperature was set to $230^{\circ} \mathrm{C}$. A $1 \mu \mathrm{L}$ injection was made and the split ratio was adjusted to 1:50. Helium was used as a carrier gas with a flow rate of $1 \mathrm{~mL} / \mathrm{min}$. The injector and detector temperatures were $240{ }^{\circ} \mathrm{C}$ and $260^{\circ} \mathrm{C}$, respectively. The mass spectrometer was operated in the electron impact (EI) mode at $70 \mathrm{eV}$ in the scan range of 50-550 m/z. Peak identification of the fatty acids in the analyzed bee pollen sample was carried out by the comparison with retention times and mass spectra of FAME component mix [64].

\subsection{Determination of Antibacterial Effect}

\subsubsection{In Vitro Antibacterial Activity of BCPE}

In order to determine in vitro antibacterial activity of bee-collected pollen extract (BCPE), the agar well diffusion method (AWD) was applied. In this process, $5 \mathrm{Gram}-$ positive bacteria and 7 Gram-negative bacteria were used (Table 4). For this purpose, initially, $40 \mathrm{mg}$ of the dried residue BCPE was weighed and transferred to a $2 \mathrm{~mL}$ Eppendorf tube (BCPE was prepared as described above). Afterwards, $2 \mathrm{~mL}$ of dimethyl sulfoxide (DMSO) was added to this tube and vortexed. After that, the extract was thoroughly dissolved in this solvent. Microorganisms kept as stock cultures at $-20^{\circ} \mathrm{C}$ were transferred to a Mueller-Hinton agar (MHA) medium via a sterile loop and incubated at $37^{\circ} \mathrm{C}$ for $24 \mathrm{~h}$. At the end of the $24 \mathrm{~h}$ incubation period, a loop full sample was taken from the single colonies and transferred to Mueller-Hinton broth (MHB) medium in $15 \mathrm{~mL}$ falcon tubes and incubated again at $37^{\circ} \mathrm{C}$ for $18 \mathrm{~h}$. After incubation of microorganisms in liquid media (MHB), turbidity was adjusted to $0.5 \mathrm{McFarland}$ standard turbidity and these bacteria suspensions were used for determination of antibacterial activity. Immediately after these procedures, $8 \mathrm{~mm}$ diameter wells were prepared on MHA media using a sterile cork-borer. Samples of pathogenic microorganisms in broths set to $0.5 \mathrm{McF}$ arland standard turbidity were spread onto MHA media to cover the entire surface with a sterile swab. After this process, $50 \mu \mathrm{L}$ of the BCPE (at a concentration of $20 \mathrm{mg} / \mathrm{mL}$ ) was taken and transferred to the wells using a micropipette. After these procedures were completed, the petri dishes were incubated at $37^{\circ} \mathrm{C}$ for $24 \mathrm{~h}$. At the end of the incubation period, the inhibition zones observed around the wells were recorded by measuring with the help of a ruler. In addition, $80 \%$ DMSO was used for negative control $[65,66]$.

\subsubsection{Broth Micro-Dilution Method}

The broth micro-dilution method was used to determine the minimum inhibition concentration (MIC) values of the BCPE. Initially, $95 \mu \mathrm{L}$ of sterile nutrient broth were transferred to each well of the 96-well polystyrene microplate using a multichannel pipette. Immediately after this procedure, $5 \mu \mathrm{L}$ of the pathogenic microorganism sample was transferred to all wells (at $0.5 \mathrm{McF}$ arland standard turbidity). After this inoculation process, $100 \mu \mathrm{L}$ of the BCPE was transferred to only the first wells (at a concentration $20 \mathrm{mg} / \mathrm{mL}$ ). Thus, $200 \mu \mathrm{L}$ suspensions were prepared only in the first wells and $100 \mu \mathrm{L}$ in the other wells. After these procedures were completed, the mixture in the first wells was thoroughly mixed with a micropipette and then $100 \mu \mathrm{L}$ of suspension was taken from the first wells and transferred to the second wells. After this suspension was mixed thoroughly, $100 \mu \mathrm{L}$ samples from the second wells were transferred to the third wells and these procedures were repeated until the last well (8th well). Thus, starting from the first well, the BCPE concentration was diluted by half in all wells consecutively $[52,67]$. 


\section{Conclusions}

Regular consumption of bee pollen is recommended in many countries, including Turkey. Therefore, to reveal the quality and physicochemical properties of the bee pollen products is of great importance for standardization studies. As a result of this study, we have determined that the mixed pollen loads from Bayburt have a high total phenolic and total flavonoid content and high antioxidant activity in parallel. The results obtained in this study revealed that the Bayburt pollen extract contained high amounts of individual phenolic compounds, such as rutin, kaempferol and quercetin. Therefore, it can be said that Bayburt bee pollen is a natural source of antioxidants. Moreover, the results obtained showed that a bee pollen sample from this region can be used as an important source of fatty acids, such as cis-4,7,10,13,16,19 docosahexaenoic acid, cis-11-eicosenoic acid, palmitic acid, and alfa linolenic acid. As a result, the fact that the bioactive content of Bayburt pollen extract is quite remarkable shows that it can be used as a dietary supplement.

Author Contributions: Y.C.G., S.C. and S.B.: Methodology, investigation, writing, reviewing, editing. All authors have read and agreed to the published version of the manuscript.

Funding: This research received no external funding.

Institutional Review Board Statement: Not applicable.

Informed Consent Statement: Not applicable.

Data Availability Statement: The data presented in this study are available on request from the corresponding author.

Conflicts of Interest: The authors declare no conflict of interest.

Sample Availability: Samples of the compounds are available from the authors.

\section{References}

1. Abouda, Z.; Zerdani, I.; Kalalou, I.; Faid, M.; Ahami, M. The Antibacterial Activity of Moroccan Bee Bread and Bee-Pollen (Fresh and Dried) against Pathogenic Bacteria. Res. J. Microbiol. 2011, 6, 376-384.

2. Coşkun, T. Fonksiyonel besinlerin sağlığımız üzerine etkileri. Çocuk Sağlı̆̆ı ve Hastalıkları Dergisi 2005, 48, 61-84.

3. Suleiman, J.B.; Bakar, A.B.A.; Mohamed, M. Review on Bee Products as Potential Protective and Therapeutic Agents in Male Reproductive Impairment. Molecules 2021, 26, 3421. [CrossRef] [PubMed]

4. Campos, M.G.R.; Bogdanov, S.; de Almeida-Muradian, L.B.; Szczesna, T.; Mancebo, Y.; Frigerio, C.; Ferreira, F. Pollen composition and standardisation of analytical methods. J. Apic. Res. 2008, 47, 154-161. [CrossRef]

5. Saisavoey, T.; Sangtanoo, P.; Chanchao, C.; Reamtong, O.; Karnchanatat, A. Identification of novel anti-inflammatory peptides from bee pollen (Apis mellifera) hydrolysate in lipopolysaccharide-stimulated RAW264. 7 macrophages. J. Apic. Res. 2021, 60, 280-289. [CrossRef]

6. Denisow, B.; Denisow-Pietrzyk, M. Biological and therapeutic properties of bee pollen: A review. J. Sci. Food Agric. 2016, 96, 4303-4309. [CrossRef]

7. Duan, H.; Dong, Z.; Li, H.; Li, W.-R.; Shi, S.-X.; Wang, Q.; Cao, W.-G.; Fang, X.-M.; Fang, A.-D.; Zhai, K.-F. Quality evaluation of bee pollens by chromatographic fingerprint and simultaneous determination of its major bioactive components. Food Chem. Toxicol. 2019, 134, 110831. [CrossRef] [PubMed]

8. Araújo, J.S.; Chambó, E.D.; Costa, M.A.P.D.C.; Da Silva, S.M.P.C.; De Carvalho, C.A.L.; Estevinho, L.M. Chemical Composition and Biological Activities of Mono- and Heterofloral Bee Pollen of Different Geographical Origins. Int. J. Mol. Sci. $2017,18,921$. [CrossRef]

9. Kostić, A. Ž; Pešić, M.; Trbović, D.; Petronijević, R.; Dramićanin, A.K.; Milojković-Opsenica, D.M.; Tešić, Ž.L. The fatty acid profile of Serbian bee-collected pollen-A chemotaxonomic and nutritional approach. J. Apic. Res. 2017, 56, 533-542. [CrossRef]

10. Mayda, N.; Özkök, A.; Bayram, N.E.; Gerçek, Y.C.; Sorkun, K. Bee bread and bee pollen of different plant sources: Determination of phenolic content, antioxidant activity, fatty acid and element profiles. J. Food Meas. Charact. 2020, 14, 1795-1809. [CrossRef]

11. Barbosa-Pereira, L.; Angulo, I.; Paseiro-Losada, P.; Cruz, J.M. Phenolic profile and antioxidant properties of a crude extract obtained from a brewery waste stream. Food Res. Int. 2013, 51, 663-669. [CrossRef]

12. Campos, M.G.R.; Frigerio, C.; Lopes, J.; Bogdanov, S. What is the future of Bee-Pollen? J. Api. Product Api. Med. Sci. 2010, 2 , 131-144. [CrossRef]

13. de Almeida-Muradian, L.B.; Pamplona, L.C.; Coimbra, S.; Barth, O.M. Chemical composition and botanical evaluation of dried bee pollen pellets. J. Food Compos. Anal. 2005, 18, 105-111. [CrossRef] 
14. Féas, X.; Vázquez-Tato, M.P.; Estevinho, L.; Seijas, J.A.; Iglesias, A. Organic Bee Pollen: Botanical Origin, Nutritional Value, Bioactive Compounds, Antioxidant Activity and Microbiological Quality. Molecules 2012, 17, 8359-8377. [CrossRef]

15. Halbritter, H.; Ulrich, S.; Grímsson, F.; Weber, M.; Zetter, R.; Hesse, M.; Buchner, R.; Svojtka, M.; Frosch-Radivo, A. Illustrated Pollen Terminology; Springer: Cham, Switzerland, 2018.

16. Barth, O.M.; Freitas, A.S.; Oliveira, É.S.; Silva, R.A.; Maester, F.M.; Andrella, R.R.; Cardozo, G.M. Evaluation of the botanical origin of commercial dry bee pollen load batches using pollen analysis: A proposal for technical standardization. Acad. Bras. Ciências 2010, 82, 893-902. [CrossRef] [PubMed]

17. Sorkun, K. Türkiye'nin Nektarlı Bitkileri, Polenleri ve Ballarl; Palme Yayıncılık: Ankara, Turkey, 2008.

18. Dufour, C.; Fournier, V.; Giovenazzo, P. Diversity and nutritional value of pollen harvested by honey bee (Hymenoptera: Apidae) colonies during lowbush blueberry and cranberry (Ericaceae) pollination. Can. Ėntomol. 2020, 152, 622-645. [CrossRef]

19. Fabre, N.; Rustan, I.; de Hoffmann, E.; Quetin-Leclercq, J. Determination of flavone, flavonol, and flavanone aglycones by negative ion liquid chromatography electrospray ion trap mass spectrometry. J. Am. Soc. Mass Spectrom. 2001, 12, 707-715. [CrossRef]

20. Khoddami, A.; Wilkes, M.A.; Roberts, T.H. Techniques for Analysis of Plant Phenolic Compounds. Molecules 2013, 18, 2328-2375. [CrossRef] [PubMed]

21. Albuquerque, B.R.; Heleno, S.A.; Oliveira, M.B.P.P.; Barros, L.; Ferreira, I.C.F.R. Phenolic compounds: Current industrial applications, limitations and future challenges. Food Funct. 2020, 12, 14-29. [CrossRef]

22. Han, X.; Shen, T.; Lou, H. Dietary Polyphenols and Their Biological Significance. Int. J. Mol. Sci. 2007, 8, 950-988. [CrossRef]

23. Kieliszek, M.; Piwowarek, K.; Kot, A.M.; Błażejak, S.; Chlebowska-Śmigiel, A.; Wolska, I. Pollen and bee bread as new healthoriented products: A review. Trends Food Sci. Technol. 2018, 71, 170-180. [CrossRef]

24. Ulusoy, E.; Kolayli, S. Phenolic Composition and Antioxidant Properties of Anzer Bee Pollen. J. Food Biochem. 2013, 38, 73-82. [CrossRef]

25. Freire, K.R.L.; Lins, A.C.S.; Dórea, M.C.; Santos, F.A.R.; Camara, C.A.; Silva, T.M.S. Palynological Origin, Phenolic Content, and Antioxidant Properties of Honeybee-Collected Pollen from Bahia, Brazil. Molecules 2012, 17, 1652-1664. [CrossRef]

26. Kalaycıŏlu, Z.; Kaygusuz, H.; Döker, S.; Kolaylı, S.; Erim, F. Characterization of Turkish honeybee pollens by principal component analysis based on their individual organic acids, sugars, minerals, and antioxidant activities. LWT 2017, 84, 402-408. [CrossRef]

27. Domenici, V.; Gabriele, M.; Parri, E.; Felicioli, A.; Sagona, S.; Pozzo, L.; Biondi, C.; Pucci, L. Phytochemical composition and antioxidant activity of Tuscan bee pollen of different botanic origins. Ital. J. Food Sci. 2015, 27, 248-259.

28. Mărghitaş, L.A.; Stanciu, O.G.; Dezmirean, D.S.; Bobis, O.; Popescu, O.; Bogdanov, S.; Campos, M.G. In vitro antioxidant capacity of honeybee-collected pollen of selected floral origin harvested from Romania. Food Chem. 2009, 115, 878-883. [CrossRef]

29. Morais, M.; Moreira, L.F.; Feás, X.; Estevinho, L.M. Honeybee-collected pollen from five Portuguese Natural Parks: Palynological origin, phenolic content, antioxidant properties and antimicrobial activity. Food Chem. Toxicol. 2011, 49, 1096-1101. [CrossRef]

30. Bayram, N.E.; Kara, H.H.; Can, A.M.; Bozkurt, F.; Akman, P.K.; Vardar, S.U.; Çebi, N.; Yılmaz, M.T.; Sağdıç, O.; Dertli, E. Characterization of physicochemical and antioxidant properties of Bayburt honey from the North-east part of Turkey. J. Apic. Res. 2020, 60, 1-11. [CrossRef]

31. Komosinska-Vassev, K.; Olczyk, P.; Kaźmierczak, J.; Mencner, L.; Olczyk, K. Bee Pollen: Chemical Composition and Therapeutic Application. Evid.-Based Complement. Altern. Med. 2015, 2015, 1-6. [CrossRef]

32. Okan, O.T.; Varlibaş, H.; Mehmet, Ö.Z.; Deniz, İ. Antioksidan analiz yöntemleri ve doğu Karadeniz bölgesinde anti-oksidan kaynağı olarak kullanılabilecek odun dışı bazı bitkisel ürünler. Kastamonu Üniversitesi Orman Fakültesi Dergisi 2013, 13, 48-59.

33. Katalinić, V.; Milos, M.; Modun, D.; Musić, I.; Boban, M. Antioxidant effectiveness of selected wines in comparison with (+)-catechin. Food Chem. 2004, 86, 593-600. [CrossRef]

34. Liu, L.; Sun, Y.; Laura, T.; Liang, X.; Ye, H.; Zeng, X. Determination of polyphenolic content and antioxidant activity of kudingcha made from Ilex kudingcha C.J. Tseng. Food Chem. 2009, 112, 35-41. [CrossRef]

35. Saxena, S.; Gautam, S.; Sharma, A. Physical, biochemical and antioxidant properties of some Indian honeys. Food Chem. 2010, 118, 391-397. [CrossRef]

36. Altiner, D.D.; Altunatmaz, S.S.; Sabuncu, M.; Aksu, F.; Sahan, Y. In-vitro bioaccessibility of antioxidant properties of bee pollen in Turkey. Food Sci. Technol. 2021, 41, 133-141. [CrossRef]

37. Mosić, M.; Trifković, J.; Vovk, I.; Gašić, U.; Tešić, Živoslav; Šikoparija, B.; Milojković-Opsenica, D. Phenolic Composition Influences the Health-Promoting Potential of Bee-Pollen. Biomolecules 2019, 9, 783. [CrossRef] [PubMed]

38. De Arruda, V.A.S.; dos Santos, A.V.; Sampaio, D.F.; Araújo, E.D.S.; Peixoto, A.L.D.C.; Estevinho, L.M.; de Almeida-Muradian, L.B. Brazilian bee pollen: Phenolic content, antioxidant properties and antimicrobial activity. J. Apic. Res. 2021, 60, 775-783. [CrossRef]

39. Bayram, N.E.; Gercek, Y.C.; Çelik, S.; Mayda, N.; Kostić, A.Ž.; Dramićanin, A.M.; Özkök, A. Phenolic and free amino acid profiles of bee bread and bee pollen with the same botanical origin-similarities and differences. Arab. J. Chem. 2021, 14, 103004. [CrossRef]

40. Thakur, M.; Nanda, V. Screening of Indian bee pollen based on antioxidant properties and polyphenolic composition using UHPLC-DAD-MS/MS: A multivariate analysis and ANN based approach. Food Res. Int. 2021, 140, 110041. [CrossRef]

41. Yang, J.; Guo, J.; Yuan, J. In vitro antioxidant properties of rutin. LWT 2008, 41, 1060-1066. [CrossRef]

42. Alimoglu, G.; Guzelmeric, E.; Yuksel, P.I.; Celik, C.; Deniz, I.; Yesilada, E. Monofloral and polyfloral bee pollens: Comparative evaluation of their phenolics and bioactivity profiles. LWT 2021, 142, 110973. [CrossRef] 
43. de Florio Almeida, J.; dos Reis, A.S.; Heldt, L.F.S.; Pereira, D.; Bianchin, M.; de Moura, C.; Plata-Oviedo, M.V.; Haminiuk, C.W.I.; Ribeiro, I.S.; da Luz, C.F.P.; et al. Lyophilized bee pollen extract: A natural antioxidant source to prevent lipid oxidation in refrigerated sausages. LWT 2017, 76, 299-305. [CrossRef]

44. Karkar, B.; Şahin, S.; Güneş, M.E. Evaluation of antioxidant properties and determination of phenolic and carotenoid profiles of chestnut bee pollen collected from Turkey. J. Apic. Res. 2021, 60, 765-774. [CrossRef]

45. Laaroussi, H.; Bakour, M.; Ousaaid, D.; Aboulghazi, A.; Ferreira-Santos, P.; Genisheva, Z.; Teixeira, J.A.; Lyoussi, B. Effect of antioxidant-rich propolis and bee pollen extracts against D-glucose induced type 2 diabetes in rats. Food Res. Int. 2020, 138, 109802. [CrossRef]

46. Bogdanov, S. The Bee Pollen Book; Bee Product Science: Muehlethurnen, Switzerland, 2011.

47. Stanley, R.G.; Linskens, H.F. Pollen: Biology Biochemistry Management; Springer Science \& Business Media: Berlin/Heidelberg, Germany, 2012. [CrossRef]

48. Çakmakçı, S.; Tahmas-Kahyaoğlu, D. Yağ Asitlerinin Sağlık ve Beslenme Üzerine Etkilerine Genel Bir Bakış. Acad. Food J. Akad. GIDA 2012, 10, 103-113.

49. Sagona, S.; Pozzo, L.; Peiretti, P.G.; Biondi, C.; Giusti, M.; Gabriele, M.; Pucci, L.; Felicioli, A. Palynological origin, chemical composition, lipid peroxidation and fatty acid profile of organic Tuscanian bee-pollen. J. Apic. Res. 2017, 56, 136-143. [CrossRef]

50. Mărgăoan, R.; Mărghitaş, L.A.; Dezmirean, D.S.; Dulf, F.V.; Bunea, A.; Socaci, S.A.; Bobiş, O. Predominant and Secondary Pollen Botanical Origins Influence the Carotenoid and Fatty Acid Profile in Fresh Honeybee-Collected Pollen. J. Agric. Food Chem. 2014, 62, 6306-6316. [CrossRef]

51. Karagözoğlu, Y.; Parlak, A.E.; Alayunt, N.Ö. Bingöl Yöresinden Toplanan Arı Polenlerinin Yağ Asidi Miktarlarının İncelenmesi. Selcuk J. Agric. Food Sci. 2012, 26, 36-41.

52. Graikou, K.; Kapeta, S.; Aligiannis, N.; Sotiroudis, G.; Chondrogianni, N.; Gonos, E.; Chinou, I. Chemical analysis of Greek pollen-Antioxidant, antimicrobial and proteasome activation properties. Chem. Cent. J. 2011, 5, 33. [CrossRef]

53. Mohdaly, A.A.; Mahmoud, A.A.; Roby, M.H.; Smetanska, I.; Ramadan, M.F. Phenolic Extract from Propolis and Bee Pollen: Composition, Antioxidant and Antibacterial Activities. J. Food Biochem. 2015, 39, 538-547. [CrossRef]

54. Cabrera, C.; Montenegro, G. Pathogen control using a natural Chilean bee pollen extract of known botanical origin. Ciencia Investigación Agraria 2013, 40, 223-230. [CrossRef]

55. Just, T.; Wodehouse, R.P. Pollen Grains, Their Structure, Identification and Significance in Science and Medicine. Am. Midl. Nat. 1936, 17, 574. [CrossRef]

56. Available online: https://www.paldat.org/ (accessed on 4 February 2020).

57. Zhou, J.; Qi, Y.; Ritho, J.; Zhang, Y.; Zheng, X.; Wu, L.; Li, Y.; Sun, L. Flavonoid glycosides as floral origin markers to discriminate of unifloral bee pollen by LC-MS/MS. Food Control 2015, 57, 54-61. [CrossRef]

58. Zhang, S.-Q.; Bi, H.-M.; Liu, C.-J. Extraction of bio-active components from Rhodiola sachalinensis under ultrahigh hydrostatic pressure. Sep. Purif. Technol. 2007, 57, 277-282. [CrossRef]

59. Magalhães, L.M.; Santos, F.; Segundo, M.A.; Reis, S.; Lima, J.L. Rapid microplate high-throughput methodology for assessment of Folin-Ciocalteu reducing capacity. Talanta 2010, 83, 441-447. [CrossRef] [PubMed]

60. Zhishen, J.; Mengcheng, T.; Jianming, W. The determination of flavonoid contents in mulberry and their scavenging effects on superoxide radicals. Food Chem. 1999, 64, 555-559. [CrossRef]

61. Apak, R.; Güçlü, K.; Demirata, B.; Özyürek, M.; Çelik, S.E.; Bektaşoğlu, B.; Berker, K.I.; Özyurt, D. Comparative Evaluation of Various Total Antioxidant Capacity Assays Applied to Phenolic Compounds with the CUPRAC Assay. Molecules 2007, 12, 1496-1547. [CrossRef]

62. Ozyurt, D.; Demirata, B.; Apak, R. Determination of total antioxidant capacity by a new spectrophotometric method based on Ce(IV) reducing capacity measurement. Talanta 2007, 71, 1155-1165. [CrossRef]

63. Fischer, U.A.; Carle, R.; Kammerer, D.R. Identification and quantification of phenolic compounds from pomegranate (Punica granatum L.) peel, mesocarp, aril and differently produced juices by HPLC-DAD-ESI/MSn. Food Chem. 2011, 127, 807-821. [CrossRef]

64. Iupac, C.P. Standard Methods for the Analysis of Oils, Fats and Derivatives. International Union of Pure and Applied Chemistry; Blackwell Scientific Publications: Oxford, UK, 1989; pp. 99-102. Available online: https://old.iupac.org/publications/books/ISBN0632033 371_compress.pdf (accessed on 23 December 2021).

65. Fatrcová-Šramková, K.; Nôžková, J.; Kačániová, M.; Máriássyová, M.; Rovná, K.; Stricik, M. Antioxidant and antimicrobial properties of monofloral bee pollen. J. Environ. Sci. Health Part B 2013, 48, 133-138. [CrossRef]

66. Kačániová, M.; Vuković, N.; Chlebo, R.; Haščík, P.; Rovná, K.; Cubon, J.; Dżugan, M.; Pasternakiewicz, A. The antimicrobial activity of honey, bee pollen loads and beeswax from Slovakia. Arch. Biol. Sci. 2012, 64, 927-934. [CrossRef]

67. Šimunović, K.; Abramovič, H.; Lilek, N.; Angelova, M.; Podržaj, L.; Možina, S.S. Microbiological Quality, Antioxidative And Antimicrobial Properties of Slovenian Bee Pollen. Agrofor 2019, 4, 4. [CrossRef] 